\title{
Severely calcified peritoneal metastases masquerading as retained barium on CT scan
}

Dhiraj Joshi, ${ }^{1}$ Sonali Kaushik, ${ }^{2}$ Peter Larsen-Disney, ${ }^{2}$ John Bush ${ }^{1}$

${ }^{1}$ Department of Clinical Radiology, Brighton and Sussex University Hospitals NHS Trust, Brighton, Sussex, UK

${ }^{2}$ Department of Gynaecological Oncology, Brighton and Sussex University Hospitals NHS Trust, Brighton, Sussex, UK

\section{Correspondence to} Dr Dhiraj Joshi,

dhiraj.joshi62@gmail.com

Accepted 15 July 2015

\section{DESCRIPTION}

A 50-year-old woman presented with non-specific abdominal pain. On examination, there was a firm palpable abdominal lump. A CT of the abdomen demonstrated a large nodular high attenuation poorly marginated intraperitoneal mass. The initial impression was that the patient might have had a recent barium examination. As there was no such history, closer inspection of the CT scan with multiformat reconstruction (figures 1-4) confirmed that the high-attenuation mass was, in fact, extensive calcification. In addition, there was evidence of a

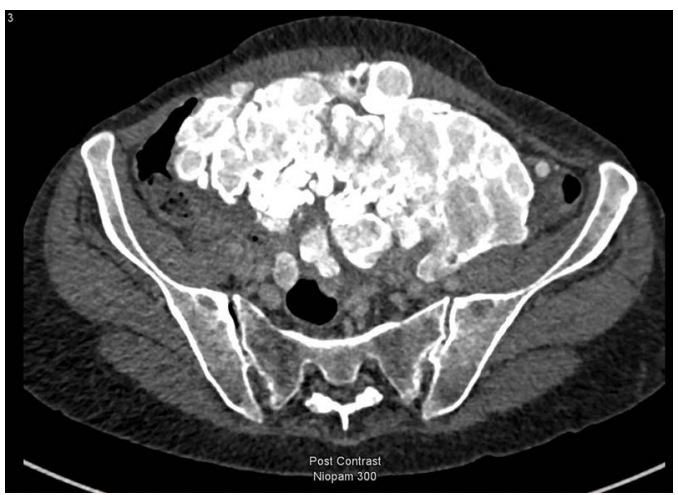

Figure 1 Calcified peritoneal metastases: CT of the abdomen in axial plane demonstrating nodular dense calcification of the peritoneum.

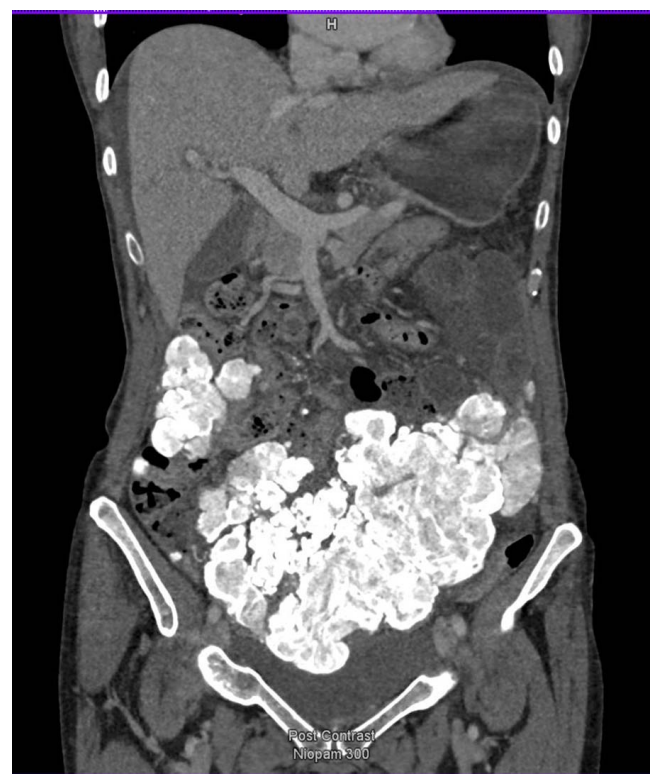

Larsen-Disney $\mathrm{P}_{\text {, et al. BMJ }}$ Case Rep Published online: [please include Day Month Year] doi:10.1136/bcr-2015211487

CrossMark
Figure 2 Calcified peritoneal metastases: CT of the abdomen in coronal plane demonstrating nodular dense calcification of the peritoneum.

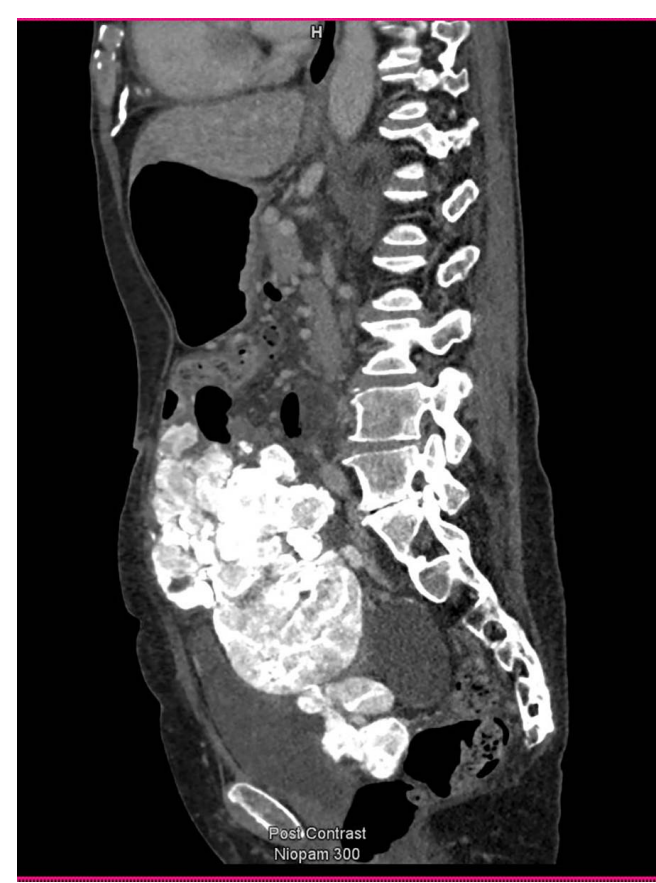

Figure 3 Calcified peritoneal metastases: CT of the abdomen in sagittal plane demonstrating nodular dense calcification of the peritoneum.

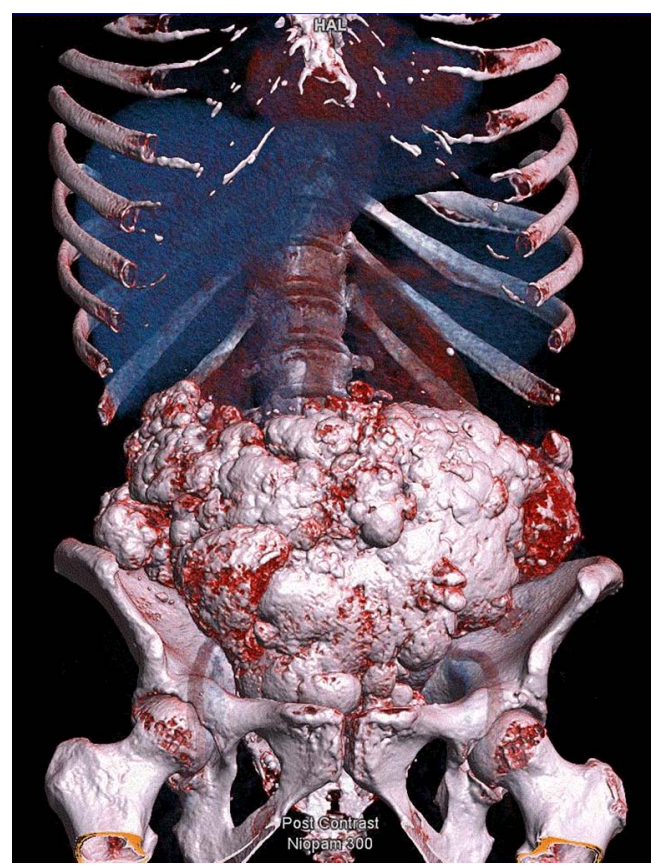

Figure 4 Calcified peritoneal metastases: volume rendered image of the $\mathrm{CT}$ of the abdomen demonstrating nodular dense calcification of the peritoneum. 
partially calcified soft tissue mass in the left adnexa. The condition was provisionally diagnosed as metastatic ovarian cancer. The laparotomy was challenging as the bowel was adhered to the peritoneal deposits. The calcified mass, the adnexal structures, $90 \mathrm{~cm}$ of small bowel and a small segment of distal colon were removed en masse with difficulty. The specimen weighed approximately $2 \mathrm{~kg}$. Histopathological analyses of the specimen confirmed high-grade papillary serous carcinoma with psammomatous calcifications replacing the left ovary and bulky calcified metastatic deposits involving peritoneum, small bowel and rectosigmoid colon.

Peritoneal metastases are common in ovarian cystadenocarcinoma. ${ }^{1}$ However, such extensive nodular calcification of the peritoneum as demonstrated in the index case is rare at presentation. Peritoneal and other metastatic deposits frequently undergo progressive dystrophic calcification of the necrotic tissue, once treatment has started. Other main differential diagnosis for peritoneal calcification includes peritoneal dialysis, previous peritonitis, hyperparathyroidism and atypical infection such as tuberculosis. ${ }^{2}$ Sheet-like linear calcification is more likely to be benign whereas nodular calcification is typically malignant. ${ }^{2}$

\section{Learning points}

- Extensive nodular peritoneal calcification can be malignant.

- The surgery can be challenging, therefore multidisciplinary management is advised.

Contributors DJ prepared the manuscript. SK prepared the images. PL-D and JB were involved in critical review of the manuscript.

Competing interests None declared.

Patient consent Obtained.

Provenance and peer review Not commissioned; externally peer reviewed.

\section{REFERENCES}

1 Mitchell DG, Hill MC, Hill S, et al. Serous carcinoma of the ovary: CT identification of metastatic calcified implants. Radiology 1986;158:649-52.

2 Agarwal A, Yeh BM, Breiman RS, et al. Peritoneal calcification: causes and distinguishing features on CT. AJR Am J Roentgenol 2004;182:441-5.

Copyright 2015 BMJ Publishing Group. All rights reserved. For permission to reuse any of this content visit http://group.bmj.com/group/rights-licensing/permissions.

BMJ Case Report Fellows may re-use this article for personal use and teaching without any further permission.

Become a Fellow of BMJ Case Reports today and you can:

- Submit as many cases as you like

- Enjoy fast sympathetic peer review and rapid publication of accepted articles

- Access all the published articles

- Re-use any of the published material for personal use and teaching without further permission

For information on Institutional Fellowships contact consortiasales@bmjgroup.com

Visit casereports.bmj.com for more articles like this and to become a Fellow 